\title{
MEYVE VE SEBZELERDE HASAT SONRASI FUNGAL HASTALIKLARIN ANTAGONISTIKK MAYALAR İLE BİYOKONTROLÜ
}

\author{
Bilal Ağırman, Meltem Necla Akalın, Hüseyin Erten* \\ Çukurova Üniversitesi, Ziraat Fakültesi, Gıda Mühendisliği Bölümü, Adana, Türkiye
}

Geliş / Received: 07.08.2018; Kabul / Accepted: 16.12.2018; Online bask1 / Published online: 18.01.2019

Ağırman, B., Akalın, M.N., Erten, H. (2019). Meyve ve sebzelerde hasat sonrası fungal hastalıkların antagonistik mayalar ile biyokontrolü. GIDA (2019) 44 (1): 31-49 doi: 10.15237/gida.GD18082

Ağrrman, B., Akahn, M.N., Erten, H. (2019). Biocontrol of postharvest fungal diseases in fruits and vegetables by antagonistic yeasts. GIDA (2019) 44 (1): $31-49$ doi: 10.15237/gida.GD18082

\section{ÖZ}

Dünya genelinde taze meyve ve sebzelerde meydana gelen ve $\% 50$ oranına kadar ulaşabilen önemli kayıplar çoğunlukla hasat sonrası hastalıklardan kaynaklanmaktadır. Günümüzde, hasat sonrası hastalıklara neden olan patojenlerin kontrolünde sentetik fungusit kullanımı ön plana çıkmaktadır. Ancak, toplumun gıda zincirinde kimyasal kalıntyı azaltma isteği ve fungusit dirençli patojenlerin gelişmesi hasat sonrası hastalıkların kontrolünde etkili ve güvenilir yeni kontrol stratejilerinin araştırılmasına yol açmıştır. Hasat edilen meyve ve sebzelerde meydana gelen kayıpların azaltılması amaciyla sentetik fungusit kullanımına alternatif olarak biyokontrol ajanların kullanımı umut verici bir yöntem olarak ortaya çıkmıştır. Biyokontrol amacıyla kullanılan çeşitli mikrobiyel ajanlar arasından özellikle mayaların önemi genellikle antibiyotik üretmemeleri, çok sayıda patojene karşı etkili olmaları vs. gibi birçok olumlu özelliğinden dolayı vurgulanmıştır. Bu derlemede; meyve-sebzelerde meydana gelen hasat sonrası hastalıklar, biyokontrol, antagonist ve fungal patojenler hakkında bilgi verilmiş, antagonizm mekanizmaları, mikrobiyel antagonistlerin biyoetkinliklerini arttırma yöntemleri ve mikrobiyel antagonistlerin ticari uygulamaları detaylı bir șekilde ele alınmıș ve literatürde yapılan son çalışmalar özetlenmiștir.

Anahtar kelimeler: Biyokontrol, antagonist, fungal patojen, meyve-sebze, maya

\section{BIOCONTROL OF POSTHARVEST FUNGAL DISEASES IN FRUITS AND VEGETABLES BY ANTAGONISTIC YEASTS}

\begin{abstract}
Postharvest diseases account for significant amount of postharvest losses of fruit and vegetables worldwide. Today, use of synthetic chemical fungicides is principal method of controlling postharvest pathogens. However, increasing concerns regarding residues of fungicides in food supply and development of fungicide resistant pathogens have prompted the search for safer alternative disease management strategies. Usage of biocontrol agents (BCAs) has emerged as one of the most promising methods to decrease postharvest losses. Among various microbial agents, use of antagonistic yeasts has been especially emphasized due to production of antibiotics is not involved in their inhibitory activities and they are effective against a wide range of pathogens. Current review provides a brief overview on postharvest diseases of fruit and vegetables, biocontrol, antagonist and fungal pathogens. Additionally, mode of action of yeasts, enhancing the bioefficacy of antagonists and commercial applications of BCAs have been discussed and recent studies in literature have been summarized.
\end{abstract}

Keywords: Biocontrol, antagonist, fungal pathogen, fruits, vegetables, yeast

\footnotetext{
* Yazışmalardan sorumlu yazar /Corresponding author;

$\triangle$ herten@cu.edu.tr @(+90) 3223386084

冝 (+90) 3223386173
} 


\section{GİRİ̧̧}

Meyve ve sebzeler; vitaminler, mineraller gibi gerekli besin ögelerini içermelerinden dolayı insan beslenmesinin önemli bir parçasını oluştururlar. Ayrica, meyve ve sebzeler besinsel lif, antioksidanlar gibi diğer gerekli bileşenleri bulundurduklarından dolayı insan sağlı̆̆ açısından önemli rol oynamaktadır (Hossain vd., 2017). Beslenme ve sağlığın bağıntilı olması konusunda artan tüketici bilinci daha fazla meyve - sebze tüketimine yol açmışır. Birleşmiş Milletler Gıda ve Tarım Örgütü (FAO) 2013 verilerine göre dünyada yaklaşık 995 milyon ton yaş sebze ve 841 milyon ton yaş meyve üretilmektedir. Ancak, dünya genelinde üretilen meyve ve sebze miktarının yaklaşık üçte biri tüketiciye ulaşmadan bozulduğundan atılmaktadır (Anonim, 2017).

Hasat öncesi ve sonrasinda taze meyve sebzelerde çeşitli bozulmalar meydana gelmektedir. Ekonomik olarak önemli kayıplara yol açan bu bozulmaların büyük çoğunluğu fungal hastaliklardan kaynaklanmaktadir. Fungal hastaliklar nedeniyle meyve ve sebzeler önemli ölçüde zarar görmekte, kaliteleri azalmakta ve genellikle raf ömürleri kısalmaktadır. Meyve ve sebzelerde taşıma, işleme ve depolamanın uygun koşullarda yapılmaması nedeniyle hasat sonrası kayıpların oranı artmaktadır. Bu kayıplar gelişmiş ülkelerde toplam meyve-sebze üretiminin \%25'ine karşıllk gelirken, gelişmekte olan ülkelerde ise bu oranın \%50'nin üzerinde olduğu bildirilmiştir (Nunes, 2012). FAO tarafindan 2011 yllinda yayinlanan raporda hasat sonrasi meyve ve sebzelerde meydana gelen kayıplarin Avrupa, Güney Amerika ve Okyanusya 'da ortalama \%29, sanayileşmiş Asya, Güney Doğu Asya, Afrika ve Latin Amerika ülkelerinde ise yaklaş1k \%38 olduğu bildirilmiştir (FAO, 2011).

Meyve ve sebzelerin fungal patojenler tarafindan kaynaklanan bozulmalara maruz kalmalar1; meyve ve sebzelerin yüksek oranda besin ve su içeriğine, düşük $\mathrm{pH}$ seviyesine sahip olmaları ve hasat sonrasinda meyve ve sebzelerin iç bozulmaya karşı göstermiş oldukları dirençte meydana gelen azalma gibi sebeplere dayandırılabilir. Hasat sonrası oluşan hastalıkların önemli bir kısmı meyve ve sebzelerde hasat esnasinda veya hasat sonrası taşıma ve paketleme sırasında meydana gelen hasarlardan kaynaklanmaktadır (Cao vd., 2013). Gidalarda hasat sonrasi bozulmalarin önemli bir çoğunluğunu temsil eden fungal patojenler Penicillium, Botrytis, Aspergillus, Monilinia, Rhizopus, Alternaria, Fusarium, Geotrichum, Gloesporium ve Mucor cinsleri olarak sayllabilir (Salas vd., 2017).

Ekonomik açıdan kayıplara ek olarak, insan sağlığ1 için tehlike oluşturan mikotoksinleri üreten Penicillium, Alternaria, Aspergillus ve Fusarium gibi bazı fungal cinsler toplum sağlığı açısından da risk teşkil etmektedir. Örneğin, hasat sonrası birçok meyvede görülen mavi küf (blue mold) hastalı̆̆ının nedeni olarak bilinen Penicillium expansum; patulin, sitrinin ve chaetoglobosin'ler gibi kanserojen ikincil toksik metabolitleri üretmektedir (Liu vd., 2013). Aspergillus niger, Aspergillus tubingensis, Aspergillus carbonarius gibi fungal türler ise gelişim aşamalarında okratoksin A (OTA) ve fumonisin B2 (FB2) gibi mikotoksinleri üretme potansiyeline sahiptir. $\mathrm{Bu}$ mikotoksinlerden OTA üzüm ve üzüm kaynaklı ürünlerde (şarap, üzüm suyu, kuru üzüm vs.) en yaygin bulunan toksin olarak tespit edilmiştir (Pantelides vd., 2015).

Günümüzde dünya genelinde meyve ve sebzelerin hasat sonrası hastalıklarını kontrol etmek amaciyla temel olarak sentetik fungisitler kullanılmaktadır. Fakat, fungisit direnci kazanan patojenlerin gelişmesi, zararlı kimyasalların gida zincirinde azaltılmasına yönelik dünya genelinde giderek artan tüketici eğilimi acil bir şekilde verimliliği yüksek, kalıntı oranı düşük, toksik olmayan çevre ve ekonomi dostu alternatif biyokontrol metotlarının bulunmasına yol açmıştır (Droby vd., 2009). Hasat sonrasi meyve ve sebzelerdeki çürümeyi yönetmek ve sentetik fungisit kullanımını azaltmak amacıyla ortaya çıkan farklı yaklaşımlar arasından antagonistik mayalar ile biyokontrol yöntemi umut verici bir gelişme olarak ortaya çımış ve önem kazanmıştır.

$\mathrm{Bu}$ derlemede meyve ve sebzelerde hasat sonras1 hastalıkların kontrolünde uygulanan yaklaşımlar ve kimyasal fungusitlerin etkileri, biyokontrol ajanı olarak mayaların önemi, ideal bir 
antagonistin sahip olmas1 gereken özellikler, biyokontrol ajanlarının etki mekanizmaları, mikrobiyel antagonistlerin biyoetkinliğini arttırma yöntemleri ve biyokontrol ürünlerinin ticari uygulamaları ele alınmıştır. Ayrıca, güncel literatür taranarak çeşitli meyve ve sebzelerde hasat sonrası meydana gelen hastalıklar, bu hastalıklara yol açan fungal patojenler ve bu patojenlerin biyokontrolünde etkili olan antagonistik mayalar hakkında bilgi verilmiştir.

\section{BIYYOKONTROL VE ANTAGONIST NEDİR?}

"Biyokontrol" yada "biyolojik kontrol" veya "biyo-koruma" terimleri doğal olarak ortamda var olan veya sonradan eklenen mikroorganizmalar1, bu mikroorganizmalar tarafindan fermantasyon sırasında üretilen çeşitli bileşenleri veya metabolitleri kullanarak bir gıdanın raf ömrünü uzatmak veya patojen ve bozucu mikroorganizmaları yok ederek gıda güvenliğini arttırmak olarak açıklanabilir (Salas vd., 2017). Biyokontrol sistemi konukçu hammadde (ürün), patojen ve antagonistik mikroorganizma arasında meydana gelen ve çevresel faktörlere bağlı olan üç yönlü bir etkileşimden oluşmaktadır (Liu vd., 2013). Biyokontrol stratejisi ile bozucu türlerin yayılmaları ve çoğalmalarını bu türlerin doğal düşmanlarını kullanarak sınırlandırmak ve kontrol altında tutmak amaçlanır (Kang vd., 2017). Burada kullanılan doğal düşman terimi ile aslında kastedilen antagonist mikroorganizmalardır. Antagonist terimi 'anti (muhalif)' ve 'against (karşısında)' kelimelerinden türetilmiştir. Antagonist mikroorganizmalar zit olan, karşıt düşman olarak tanımlanabilir ve ana karakteri engellemekle yükümlüdürler.

Antagonizm doğada mikroorganizmaların biyolojik denge kurma yaklaşımlarından birisidir. $\mathrm{Bu}$ yaşam biçiminde bir arada bulunan iki mikroorganizmadan biri diğerine doğrudan ya da dolaylı olarak zarar verir ve gelişmesini, çoğalmasını olumsuz olarak etkiler ve yaşamını sinırlandırır ya da ortadan kaldırır. Sharma vd. (2009) tarafindan meyve ve sebzelerde meydana gelen hasat sonrasi hastalıkların mikrobiyel antagonistler ile kontrolünde iki temel yaklaşım olduğu bildirilmiştir. İlk yaklaşım olarak ürünün üzerinde doğal olarak zaten var olan epifitik mikroorganizmaların gerektiğinde desteklenerek yönetilmesi ve patojenlere karşı kullanılması, ikinci yöntem ise hasat sonrası patojene karşı rekabet etme yeteneğine sahip olan ancak dışardan getirilip ortam içerisine yerleştirme yoluyla mikrobiyel ajanların yapay bir şekilde patojenlere karşı tanıştırılması olarak bildirilmiştir.

Hasat sonrası meyve ve sebze çürümelerini önlemek amacı ile biyokontrol ajan (BYA) olarak başta mayalar olmak üzere küfler, laktik asit bakterileri, Gram pozitif ve Gram negatif bakteriler mikrobiyel antagonist olarak kullanılmaktadır (Çizelge 1) (Sharma vd., 2009; Lamont vd., 2017). Literatürde kullanılan birçok farklı mikroorganizma türü arasında özellikle mayaların biyokontrol ajanı olarak kullanımları ön plana çımıştır. Bunun sebepleri arasında mayaların büyük ölçekli ticari üretimleri, fermantasyon, depolama ve kullanımlarına dair önemli ölçüde bilgi birikiminin bulunmasının yanı sıra mayaların inhibisyon aktivitileri içerisinde özellikle antibiyotikler gibi ikincil metabolit madde üretiminin bulunmamasıdır (Liu vd., 2013). Gidalarda antibiyotik üretici mikroorganizma kullanilması sonucu meyvelerde bulunan ve aynı zamanlarda insanlara karşı patojen olan mikroorganizmalarda antibiyotik direnci gelişimine neden olabileceği endişeleri antibiyotik üreticisi olmayan maya türlerinin hasat sonrasi hastalıklarda kullanımı stratejisini yaygınlaştırmaktadır (Spadaro ve Droby, 2016).

\section{MAYALARIN BIYYOKONTROLDEKI ÖNEMİ VE İDEAL BİR ANTAGONISTTE ARANAN ÖZELLİKLER}

Hasat sonrasi meyve-sebze patojenlerinin kontrolü meyve-sebze sanayisinin karşılaştığ en önemli zorluklardan birisidir. Küflerin ürün üzerinde çoğalması önemli miktarlarda ekonomik kayıplara yol açarken diğer taraftan meyvesebzelerin mikotoksin kontaminasyonuna uğramasından dolayı ciddi sağlık problemlerini de beraberinde getirmektedir. Sentetik fungusit kullanımı meyve-sebzelerde fungal hastalıkları kontrol etmede en yaygin yöntem olarak kullanılmaktadır. Öte yandan, sentetik fungusit 
kullanımının yol açtığ1 akut ve sinerjik etkilerden dolayı fungusit kullanımı ciddi yasal kontroller altında yürütülmektedir (de Paiva vd., 2017). Avrupa Gıda Güvenliği Otoritesi (EFSA) 2014 yllında yaptığ çalışmada incelenen gida örneklerinin yaklaşık \%45'inde sentetik bileşen kalıntısına rastlandığını ve örneklerin \%1.9'unun izin verilen sınırların üzerinde kalıntı içerdiğini belirtmiştir. Ayrıca, teste tabii tutulan gidalarda Avrupa Birliği tarafindan onaylanmayan pestisitlerin de kullanıldığı bildirilmiştir (EFSA, 2014).

Çizelge 1. Meyve ve sebzelerin hasat sonrası hastalıklarının kontrolünde etkili olan mikrobiyel 
Hasat sonrası bozulmalarda antagonistik mayaların önemi

Çizelge 1. Devam

\begin{tabular}{lllll}
\hline Antagonist & Parazit & Ürün & Hastalık & Referans \\
\hline Paenibacillus pasadenensis & Botrytis cinerea & Üzüm & Gri küf & Passera vd., 2017 \\
\hline Paenibacillus polymyxa & Botryosphaeria dothidea & Elma & Beyaz çürüklük & Kim vd., 2016 \\
\hline Pichia caribbica & Penicillium expansum & Elma & Mavi küf & Cao vd., 2013 \\
\cline { 2 - 5 } & Penicillium expansum & Elma & Mavi küf & Mahunu vd., 2016 \\
\hline Pichia guilliermondii & Botrytis cinerea & Kivi & Gri küf & Sui ve Liu., 2014 \\
\hline Pichia membranaefaciens & $\begin{array}{l}\text { Colletotrichum } \\
\text { gloerosporioides }\end{array}$ & Turunçgil & Antraknoz & Zhou vd., 2016 \\
\hline $\begin{array}{l}\text { Rhodosporidium } \\
\text { paludigenum }\end{array}$ & Penicillium expansum & Armut & Mavi Küf & Sun vd., 2018 \\
\hline Rhodotorula minuta & Geotrichum citri-aurantii & Portakal & Ekşi (aci) çürüklük & Ferraz vd., 2016 \\
\hline Saccharomyces cerevisiae & Botrytis cinerea & Üzüm & Gri küf & Parafati vd., 2015 \\
\cline { 2 - 5 } Penicillium digitatum & Limon & Yeşil küf & Perez vd., 2016 \\
\hline Starmerella bacillaris & Botrytis cinerea & Üzüm & Gri küf & Lemos Junior vd., \\
\hline $\begin{array}{l}\text { Wickerbamomyces } \\
\text { anomalus }\end{array}$ & Penicillium italicum & Çilek & Mavi küf & Parafati vd., 2017 \\
\cline { 2 - 5 } & Botrytis cinerea & Üzüm & Gri küf & Parafati vd., 2015 \\
\hline Yarrowia lipolytica & Talaromyces rugulosus & Üzüm & Çürüme & Yang vd., 2017 \\
\hline
\end{tabular}

Tüketicilerin pestisit kalıntıs1, zararlı mikroorganizma ve toksin içermeyen gidalar tüketmeye yönelik arzusu, sentetik kimyasalların çevre üzerine olumsuz etkileri, fungusitlerin kullanımına devam edilmesi sonucu dirençli patojen cinslerinin çoğalması endişeleri ve sentetik kullanımına dair katı yasal düzenlemelerin bulunmas1 kimyasal olmayan kontrol yöntemlerinin araştırılmasına yol açmıştır (Romanazzi vd., 2017; Terao vd., 2017). Genellikle bakteri ve mayaları kullanmayı esas alan biyolojik kontrol yöntemleri ürünleri korurken, aynı zamanda net verimi de arttırmaktadır. Ancak, antagonistik bakterilerin ana inhibisyon mekanizmasinın antibiyotik üretimi olmas1 nedeniyle, biyokontrol ajanı olarak mayaların kullanımına ilgi artmaktadır (Liu vd., 2017).

Biyokontrol ajanı olarak kullanılan mayaların etki mekanizmaları arasında, çoğu küf ve bakteriyel antagonistin sahip olduğu antibiyotik, toksin ve alerjen spor üretme mekanizmalar1 bulunmamaktadır. Ayrica mayalar bitkide patojenlere karşı verilen olumlu tepkileri teşvik ederken, ortamda bulunan bozucu ve diğer mikroorganizmaların olumsuz etkilerini de azaltmaktadır (Aloui vd., 2015; Parafiti vd., 2015).
İdeal bir antagonistte bulunmasi gereken özellikler şöylece özetlenebilir; genetik olarak stabil olmalı, düşük konsantrasyonlarda etkili olabilmeli, besin gereksinimi bakımından çok seçici olmamalı, olumsuz çevresel koşullarda dahi canlilığını devam ettirebilme yeteneğine sahip olmalı, çeşitli gidalarda birçok farklı patojene karşı etkili olabilmeli, ucuz gelişme ortamında çoğalmaya yatkın olmalı, uzun raf ömrüne sahip formülasyon sağlayabilmeli, dağıtımı kolay olmalı, hasat sonrası kullanılan kimyasallara dirençli olmalı, insan sağlığına zararı olmamalı ve dayanıklı olmalıdır (Droby vd., 2009; de Paiva vd., 2017).

Mayaların ideal bir antagonistte arzulanan özelliklerin çoğuna sahip olması antagonist seçimi ve uygulamasinda öncelikle tercih edilmelerine neden olmuştur. Mayaların kuru yüzeylerde uzun süre boyunca kolonize olabilmesi, basit besin gereksinimlerine ihtiyaç duyması, meyvesebzelerin yaralı bölgelerinde hızlı bir şekilde çoğalabilmeleri ve patojenlerin geniş spektrumuna karşı etkili olabilmeleri öne çıan özelliklerdendir (Pantelides vd., 2015). Ayrica mayalar, hasat öncesi ve sonrasi ürünün bulunduğu ortamda oluşabilecek aşırı yüksek veya düşük sıcaklıklar, düşük oksijen seviyeleri, $\mathrm{pH}$ dalgalanmalan, UV 
1şını ve geniş bağıl nem aralığı gibi koşulları tolere edebilme yeteneğindedir. Bu özelliklerinin dışında mayaları ön plana çıkaran bir diğer özellik ise, mayaların meyve-sebzelerin dokusu içerisindeki ortamın yüksek şeker konsantrasyonu, yüksek osmotik basınç ve düşük pH gibi koşullarına hızlı bir şekilde adapte olabilmeleridir (Spadaro vd., 2010; Spadaro ve Droby, 2016). Mayaların en önemli özelliklerinden bir diğeri ise meyve-sebze yüzeyleri, toprak, deniz suyu, bitkilerin kökleri ve yaprakları gibi pek çok ortamda yaygın bir şekilde bulunmalarıdır (Liu vd., 2013). Örneğin; Kalogiannis vd. (2006) domates yapraklarından Rhodotorula glutinis izole ederken, Tang vd. (2015) kivi meyvesinden Candida diversa suşunu, CamposMartínez vd. (2016) ise avokado meyvesinden Candida intermedia mayasını izole etmişlerdir. İlaveten, mango meyvesinden Saccharomyces cerevisiae, mandalina ve kabak'tan ise Candida tropicalis suşlarının izole edildiği bildirilmiştir (Zhimo vd., 2017).

Yukarıda belirtilen olumlu özelliklerden dolay1 farklı kaynaklardan izole edilen mayaların biyokontrol ajanı olarak kullanım potansiyelleri son 30 yl içerisinde birçok araştırmacı tarafindan incelenmiştir (Liu vd., 2014; Perez vd., 2017; Sun vd., 2018). Son yillarda ise yapilan araştırma sayısında önemli bir artış söz konusudur.

\section{ANTAGONIZM MEKANIZMALARI}

Antifungal mikroorganizmalar kullanarak fungal bozulmaları kontrol etmek oldukça karmaşık bir durumdur. Çünkü biyokontrol işleminin başarısı gıdanın kendisi (içerisinde doğal mikroflorasını barındıran), fungal bozucular, antifungal mikroorganizmalar ve bulundukları çevre olmak üzere dört ana aktör arasındaki etkileşim ağına bağlıdır (Şekil 1). Gıdanın tipine ve antifungal mikroorganizmaya bağlı olarak tek mekanizma veya birkaç mekanizma birlikte olacak şekilde farklı etki mekanizmaları devreye girerek bozucu fungusların inhibisyonunda rol alır (Liu vd., 2013; Salas vd., 2017). Günümüzde halen biyokontrol ajanları olarak kullanılan mikroorganizmaların patojen inhibisyon mekanizmaları tam olarak açıklanamamaktadır. Ancak, patojen ve antagonist arasinda gerçekleşen besin ve yer rekabeti hasat sonrası hastalıkları kontrolde en önemli etki mekanizması olarak literatürde açık bir şekilde ifade edilmiştir (Spadaro ve Droby, 2016; Mahunu vd., 2016; Oregel-Zamudio vd., 2017; Pesce vd., 2018). Biyokontrolde etkili olan diğer mekanizmalardan bazıları ise; antibiyozis, direnç indüksiyonu, hücreler arasi temas, mikoparazitizm, litik enzimlerin üretimi, oksidatif stres, demir kullanımı, uçucu organik bileşiklerin üretimi, biyofilm oluşturma ve çevreyi algilama sistemi (quorum sensing) olarak siralanabilir (Sharma vd., 2009; Liu vd., 2013; Ruiz-Moyano vd., 2016; González-Estrada vd., 2017).

Karbonhidrat, azot ve oksijen gibi besin elementleri ve alan için rekabet antagonist mayaların fungal patojenleri kontrolde kullandıkları ana etki mekanizmalarının başında gelmektedir. Antagonist doğru zamanda, doğru yerde, yeterli konsantrasyonda bulunuyorsa ve ortamda bulunan besin kaynaklarını patojenlerden daha etkili ve hızlı bir şekilde kullanabiliyorsa bu mekanizma biyokontrolde başarılı sonuçlara yol açmaktadır (Spadaro ve Droby., 2016).

En önemli antagonizm mekanizması olarak kabul edilen alan ve besin için yarışma mekanizması alan-yer için yarışma, besin için yarışma ve patojen hiflere bağlanma olarak 3 ana başlık içermektedir. Alan için yarışma mikrobiyel antagonistin patojene göre meyve ve sebzede çok daha hızlı gelişme prensibine dayanmaktadır. Meyve ve sebzelerde meydana gelen kesik ve hasarl1 alanlarda antagonistin hızlı bir şekilde çoğalıp kolonize olması çürümeyi önlemekte oldukça önemlidir. Mikrobiyel antagonistin patojen hiflerine bağlanması besin için yarışma açısından önemli bir faktör olarak görülmektedir ve Pichia guillermondi ile Penicillium italicum arasındaki etkileşimler ile bu durum gösterilmiştir (Arras vd., 1998). In vitro çalışmalarda bakteri veya mayaların direk olarak patojen hiflerine bağlanması sonucu antagonistlerin besinleri patojenden daha hizlı aldikları ve bunun sonucu olarak da patojenlerin gelişmesinin ve spor çimlenmesinin önlendiği bildirilmiştir (Sharma vd., 2009).

Mikrobiyel antagonistlerin patojenlerle besin için yarışması hipotezinin antagonistlerin temel etki mekanizmalarından biri olduğu çeşitli çalışmalarla 
açığa kavuşturulmuştur. Turunçgillerde Pichia guillermondii Penicillium digitatum'a karş1 (Arras vd., 1998), şeftalide Pichia caribbica Rhiøopus stolonifer'e karş1 (Xu vd., 2013), elmada Pichia anomala Botrytis cinerea'ya karş1 (Kwasiborski vd., 2014) besin için yarışma mekanizması ile başarılı bulunmuştur.

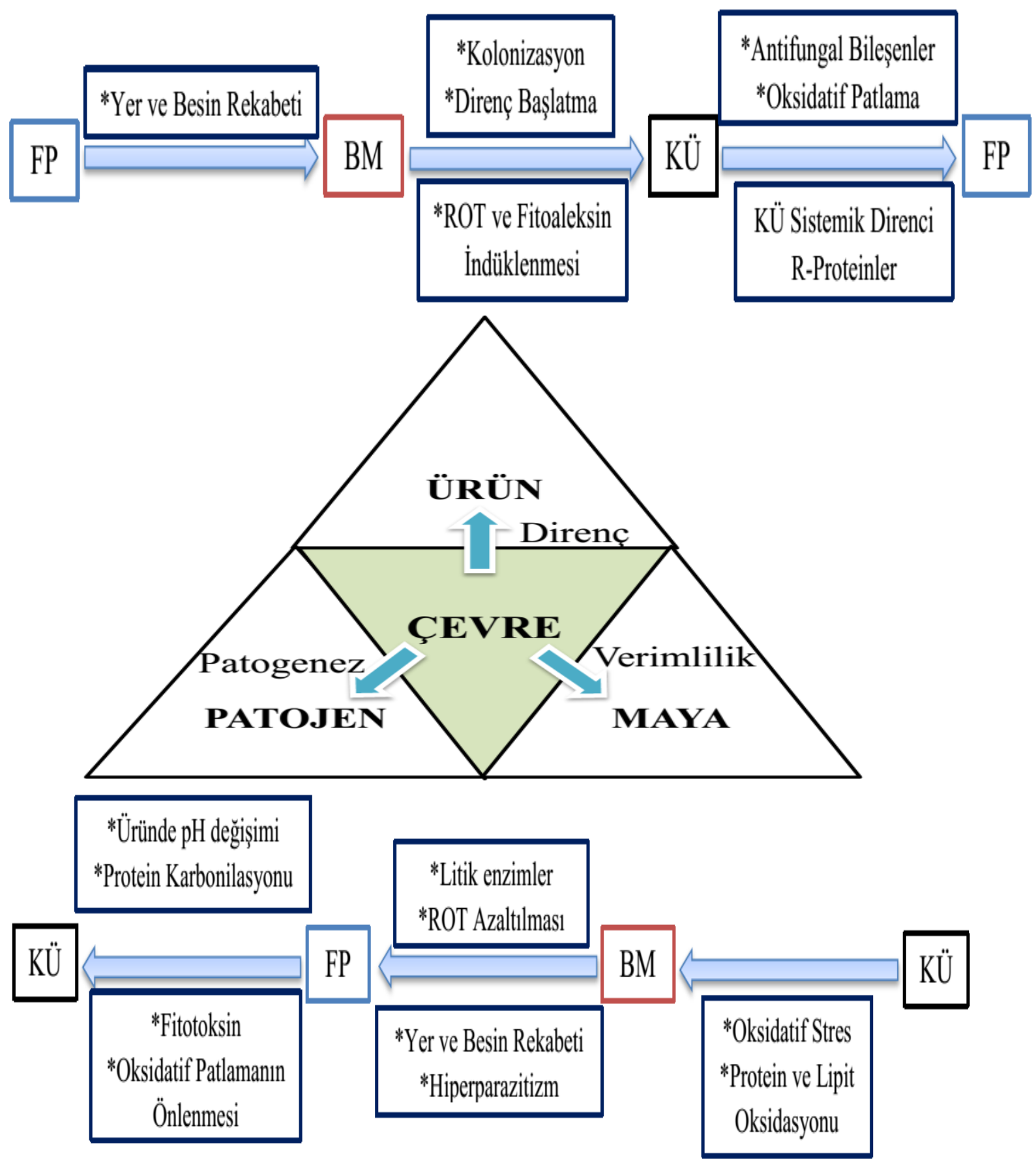

Şekil 1. Konukçu ürün, antagonist maya, fungal patojen ve çevre arasında olabilecek muhtemel etkileşimler (KÜ: Konukçu ürün, FP: Fungal patojen, BM: Biyokontrol maya, ROT: Reaktif oksijen türevleri) 
Patojen ve antagonist mikroorganizmanin besin için yarışma mekanizmaları içerisinde özellikle demir elementi için rekabet ayrı bir mekanizma olarak ele alınmaktadır. Demirin $\left(\mathrm{Fe}^{+3}\right)$ biyolojik olarak önemli bir element olmasi; demirin hemen hemen bütün mikroorganizmaların gelişmesi için gerekli bir bileşen olması, hücre içerisinde birçok önemli proseste rol alan çok sayıda fungal enzim için kofaktör olması, katalaz ve sitokrom gibi hemoproteinlerin ve elektron taşıyıcı proteinlerin yapisinda bulunmasindan kaynaklanmaktadir (Nally vd., 2015; Spadaro ve Droby., 2016). Mayalar biyofilm oluşturarak meyvelerin veya patojenlerin hücre dokularına bağlanmakta, hücre dışı enzimler üreterek ve ortamdaki demiri tüketerek patojenin gelişmesini engellemektedir. Demir rekabeti ile biyokontrolü sağlamada özellikle Metschnikowia spp. cinsi mayalar ön plana çıkmıştır. Bu cins mayalar demir şelasyonu yapan ligandlar veya siderofor üreterek çeşitli bakteri, maya ve küflerin gelişimini kuvvetli bir şekilde antagonize edebilmektedir (Liu vd., 2017). Metschnikowia cinsine bağlı farklı türler çeşitli meyve ve sebzelerde farklı küflerin gelişimini durdurmada başarilı olmuştur. Metschnikowia fructicola üzümlerde Botrytis cinerea (Parafiti vd., 2015), elma ve kirazda Penicillium expansum (Spadaro vd., 2013; de Paiva vd., 2017) ve nektarinlerde Monilinia laxa'nın (Ruiz-Moyano vd., 2016) biyokontrolünde başarılı bulunurken Metschnikowia pulcherrima elmada Botrytis cinerea ve Penicillium expansum'a karşı demir tüketimi yoluyla yarışarak patojenlerin biyokontrolünü sağlamıştır (Saravanakumar vd., 2008).

Parazitizm, antagonist patojen üzerinde beslendiğinde ortaya çıkar ve fungal hücre yapılarının doğrudan yok edilmesine veya tahribine (liziz) yol açar (Spadaro ve Droby., 2016). Parazitizm sistemi; fungal hifler ile antagonist mikroorganizmanın doğrudan fiziksel etkileşimi ve bu arada antagonist tarafindan litik enzimlerin üretimi vasitasiyla aktivite gösterir (González-Estrada vd., 2017). Fungal hücre duvarlarının yapısal omurgası kitinden oluşan düzenli şekilde sıralanmış tabakalardan oluşurken dolgu malzemesi olarak ise amorf halde bulunan $\beta-1-3$ glukan bulunmaktadır. Glukan, fungal hücre duvarlarının kuru madde ağırlı̆̆ının yaklaşık \%50- 60'ını oluşturan en önemli polisakkarittir. Kitin ise doğrusal ve homopolimer yapıda, asetillenmiş amino şeker N-asetilglukozaminin beta-1,4bağlantılı alt birimlerinden oluşur. İpliksi fungilerin hücre duvarının $\% 20$ veya daha fazlasını kitin oluşturur (Spadaro ve Droby, 2016). Dolayısıyla, fungal hücre duvarlarını parçalamak için $\beta-1-3$ glukanaz ve kitinaz başta olmak üzere proteazlar ve çeşitli enzimlerin aktivitelerine ihtiyaç duyulur. Antagonistik mayaların litik enzim üretme yetenekleri biyokontrol aktivitelerinde önemli bir rol oynar. $\mathrm{Bu}$ mekanizma antagonistlerin fungal patojen hiflerine yapışarak litik enzimler salgılanması ile başlarken, fungal hiflerin yapisinda bozulma ve stoplazmik bileşenlerin dışarı sızması ile devam etmekte ve hücrenin lize olması ile sonuçlanmaktadır (Bautista-Rosales vd., 2013). Pichia guillermondiinnin domates üzerindeki peroksidaz, polifenol oksidaz, superoksit dismutaz, katalaz, fenilalanin amanyum liyaz, kitinaz ve $\beta$-1,3-glukanaz enzim aktivitelerini arttırdığ1 Zhao vd. (2008) tarafindan belirlenmiştir. Böylelikle P. guillermondii'nin meyve üzerinde bulunan savunmacı enzimler vasitasiyla patojenlere karşı meyvenin direnç mekanizmasını başlattığını ve bunun da $P$. guillermondii nin antagonizm mekanizmalarından biri olduğu bildirilmiştir. Benzer şekilde Aurebasidium pullulans'in elmaların kesik bölgelerinde 1,3glukonaz, peroksidaz ve kitinaz enzim aktivitelerini arttırdığ ve bunun sonucunda elmaların hasarlı bölgelerinde iyileşme olduğu ve Penicillium expansum'a karşı elmalarda savunma mekanizmasının uyarıldığı bildirilmiştir (Ippolito vd., 2000).

Antagonistik mayaların sergilemiş olduğu biyokontrol mekanizmalarından birisi de reaktif oksijen türevlerini (ROT) tolere etme yetenekleridir. Çünkü antagonistik mayalar meyve ve sebzelerin yaralı bölgelerine uygulandıklarında reaktif oksijen türevleri ile karşı karşıya kalırlar ve bu oksidatif strese neden olur. Oksidatif stres mayaların canlilı̆̆ ve performansinı etkilemektedir (Macarisin vd., 2010). Bu nedenle mayaların hasat sonrasi hastaliklarda biyokontrol ajanı olarak kullanılabilme potansiyelleri ile oksidatif stres arasındaki ilişki incelenmiş ve mayaların yüksek oranlardaki oksijenin üstesinden 
gelebilecek kapasiteye sahip olmasinin ideal bir biyokontrol ajanı için önemli özelliklerden biri olduğu belirtilmiştir (Castoria vd., 2003).

Ürünlerde reaktif oksijen türevlerinin üretilmesi patojenik olan ve olmayan mikroorganizmalara karşı gösterilen ilk tepkidir. Antagonistik mayalar meyve dokularında reaktif oksijen türevlerinin üretilmesini ve bunun meyvelerde bir savunma sinyali olarak kullanılmasını etkilemiştir. Uyumlu olmayan konak-parazit etkileşimlerinde ürün dokusunda yüksek miktarda üretilen reaktif oksijen sonucunda patojen saldirları esnasinda oksidatif patlamalar meydana gelmekte ve bu patlamalar meyve-sebzeler için patojenlere karşı ev sahibi ürün tarafindan gösterilen reaksiyon olarak tanımlanmaktadır (Liu vd., 2013). Diğer taraftan uyumlu konak-parazit etkileşiminde ürün dokusunda reaktif oksijen miktarında herhangi bir artış gözlenmemektedir (Spadaro ve Droby., 2016).

Yüksek miktarda reaktif oksijen türevlerini tolere etme yeteneğinin biyokontrol ile ilişkili olduğunu gösteren ilk çalsşma Cryptococcus laurentii ve Rhodotorula glutinis mayalarını kullanarak Castoria vd. (2003) tarafindan yapılmıştır. Bu çalışmadan elde edilen bulgularla oksidatif stresin biyokontrol sistemindeki rolü ayrıca hücreler arası veya hücre içi seviyelerde antagonistik hücre veya meyve dokusu üzerine doğrudan veya dolaylı olarak etkisinin olduğu ileri sürülmüştür.

Antagonistik hücrelerin kolonizasyonunu takiben meyvelerin yaralı bölgelerinde oksidatif patlamalar meydana gelmesi, meyve direnç sisteminin aktifleşmesini sağlamakta ve bu durum antagonist mayaların önemli etki mekanizmalarından biri olarak kabul edilmektedir (Macarisin vd., 2010). Antagonistik hücrelerin bu yolu kullanabilmeleri için yüksek miktarda oksidatif stresi tolere edebilmeleri gerekir. Bu amaçla Liu vd. (2012) Candida oleophila mayasını ölüm seviyesinde oksidatif strese maruz bırakmış ve bunun sonucu olarak mayanın ölüm seviyesi üzerindeki oksidatif strese ve ayrıca sıcaklığa karşı toleransının arttığını belirlemisslerdir. Bunun sonucu olarak strese adapte olan mayaların strese adapte edilmeyen mayalara kiyasla oldukça yüksek seviyede biyokontrol etkinliğine sahip oldukları bildirilmiştir (Liu vd., 2012).

\section{MİKROBİYEL ANTAGONİSTLERİN BIYYOYARARLILIĞININ ARTTIRILMASI}

Antifungal kültürlerin seçimi ve aktivitelerinde etkili olan moleküllerin belirlenmesinden sonraki aşama bu kültürlerin verimliliklerinin veya etki spektrumlarının (inhibe edilen tür / suş sayısı) arttırlmasıdır. Bunun dişında antagonistin kullanılabileceği ürün tiplerinin belirlenmesi ve bu ürünlere antagonist kültürlerin hangi yöntemlerle uygulanacağının bulunması öncelikle cevap verilmesi gereken sorulardandır (Salas vd., 2017). Günümüzde meyve ve sebzelerde hasat sonras1 hastalıkların kontrolü antagonist kültürlerin tek başlanına kullanımı ile \%100 sağlanamamaktadır. Mayalar; ticari ürün formülasyonları ve büyük ölçekli fermantasyonlar sırasında yüksek sıcaklık, dondurarak/püskürterek kurutma (kuruma) ve oksidatif stres gibi çeşitli olumsuz çevresel koşullara maruz kalmaktadır. Bu nedenlerden dolay1 mayaların ticari üretimleri sirasında stres toleranslarının, canlilik ve performanslarının geliştirilmesi sonucu biyoyararlılıklarını arttırmak amacı ile çeşitli yaklaşımlar kullanılmaktadır (Sharma vd., 2009; Liu vd., 2013). Depolama sırasında fiziksel ve kimyasal çevrede değişiklik yapılması, karışık kültür kullanımı, mikrobiyel kültür içerisine düşük dozlarda fungusit ilavesi, mikrobiyel kültürlere tuz katkılarının eklenmesi, mikrobiyel kültürlere besin maddesi veya bitkisel ürün ilavesi, mikrobiyel kültürlerin çeşitli fiziksel uygulamalarla, diğer yaklaşımlar ve katkılarla birlikte kullanılmas1 antagonistlerin biyoyararlılıklarının arttırılmasında kullanılan başlica stratejilerdir (Sharma vd., 2009; Salas vd., 2017). Belirtilen yaklaşımların kullanılması ile olumlu sonuçlar alınan bazı çalışmalar aşağıda özetlenmiştir.

Candida sake gelişme ortamına gliserol, glikoz ve trehaloz eklenerek mayanın hücre içi poliol ve şeker içeriği arttırlmış ve bu şekilde C. sake mayasının elmalarda P. expansum’a karşı gösterdiği su stres toleransinın ve biyokontrol etkinliğinin arttı̆̆1 belirlenmiş̧ir (Teixido vd., 1998). Benzer bir çalş̧mada $C$. laurentī'nin gelişme ortamı için trehaloz içeren besiyeri kullanılmıs ve böylece 
hücre içi trehaloz miktarı arttırılan C. laurentii nin kontrollü atmosfer şartları altında ve düşük sicakliklarda kurutulmasina rağmen canlilık ve biyokontrol etkinliğinin arttı̆̆ belirlenmiştir (Li ve Tian, 2006).

Meyve ve sebzelerdeki bozulmaların mikrobiyel antagonistler tarafindan kontrolünde tuz katkılarının biyoetkinliği geliştirdiği belirlenmiştir. $\mathrm{Bu}$ amaçla kullanılan farklı tuz katkıları arasından kalsiyum klorür, kalsiyum propiyonat, sodyum karbonat, sodyum bikarbonat ve potasyum metabisülfit, etanol ve amonyum molibdatın mikrobiyel antagonistlerle birlikte kullanımının meyve ve sebzelerde oluşan hasat sonrası hastalıkların kontrolünde oldukça etkili ve başarılı olduğu bildirilmiştir (Sharma vd., 2009).

Tuza adapte edilen Rhodosporidium paludigenum mayasının düşük su aktivitesi ve donma stresi koşulları altında tuza adapte edilmeyen hücrelere kıyasla daha yüksek seviyede canlılık sergilediği bildirilmiştir (Wang vd., 2010). Bir başka çalışmada ise ön 1 sitma işleminin $\left(40^{\circ} \mathrm{C}\right.$ 'de 30 dakika) $M$. fructicola'nın yüksek sicaklıklara ve oksidatif strese karşı gösterdiği toleransı arttırdığ1 belirlenmiştir (Liu vd., 2011). Yukarıdaki çalışmalar da stres ön adaptasyon uygulamasının antagonist mayalarda yüksek seviyelere karşı gösterilen stres toleransı ve biyokontrol etkinliğini geliştirdiği görülmüştür. Bu nedenle farklı çevresel koşullar altında meyvelerde görülen hasat sonrası bozulmaları önleyebilmek amaciyla biyokontrol ürünlerinin güvenilirliğini ve etkinliğini arttırabilmek için mayalara abiyotik strese karşı ön-adaptasyon uygulanması ticari olarak uygulanabilir görülmektedir.

İmazalil ve thiobendazole gibi bazı fungisitler hasat sonrası hastalıkları kontrolde son derece etkilidir. Bu fungusitlerle aynı seviyede etkili olan bir mikrobiyel antagonist bulmak oldukça zordur. $\mathrm{Bu}$ nedenle mikrobiyel antagonist ve fungisitleri kombine ederek etkili biyokontrolü sağlayan bir yaklaşım bulunmaktadır. Mikrobiyel antagonist ve fungusitin birlikte uygunluk içinde aktivite gösterdiği yöntem fungusit seviyesi azaltılmış güçlü biyokontrol avantajı sunmaktadır. Meyve ve sebzelerde hasat sonrasi hastaliklarin bu yaklaşımla etkili bir şekilde kontrol edilebileceği kabul edilmektedir. Örneğin; bazı mikrobiyel antagonistlerin düşük miktarda fungusit eklenerek bazı ticari formülasyonları geliştirilmiş ve bu şekilde hasat sonrası hastalıkların kontrolünde \%100'e yaklaşan oranlarda başanı sağlanmıştır. Elma ve armutlarda depolama esnasinda oluşan $P$. expansum kaynakl1 hastalıklar Pseudomonas syringae'nin düşük dozlarda cypronidil ile birlikte kullanılması sonucu etkili bir şekilde kontrol edilmiştir. Yapılan çalışmalarda genellikle maya ve düşük dozda fungusit kullanımı sonucu oluşan sinerjik etkinin mayanın ve fungusitin tek başına kullanıldıkları zaman sergiledikleri etkiden daha yüksek olduğu görülmüştür (Sharma vd., 2009).

Karabulut vd. (2010) tarafindan yapılan çalışmada şeftali, nektarin ve erik meyvelerinde bozulmaya neden olan Monilinia fructicola biyokontrolünde 24, $50,55,60,65$ veya $70^{\circ} \mathrm{C}$ sicaklikta bulunan sulara kısa süreli (30 veya 60 saniye) daldırma işlemi gerçekleştirilerek işlemin etkinliği değerlendirilmiştir. Market şartlarına benzer koşullar sağlamak amacıyla inoküle edilen meyveler $20^{\circ} \mathrm{C}^{\prime}$ de 5 gün veya $20^{\circ} \mathrm{C}^{\prime}$ de 5 gün depolama ile takip edilen $0^{\circ} \mathrm{C}$ ve $\% 95$ relatif nemde 30 gün bekletilmiştir. Sicaklığ1 $55^{\circ} \mathrm{C}$ olan suya 60 saniye veya $60^{\circ} \mathrm{C}$ 'de bulunan suya 30 veya 60 saniye daldırma işleminin meyvelerde çürüme oran1 ve şiddetini önemli miktarda azalttı̆̆1 belirlenmiştir. Ayrıca sıcaklığ $65^{\circ} \mathrm{C}$ veya daha fazla olan sulara meyveleri daldırma işleminin meyve yüzeylerinde şiddetli yaralanmalara neden olduğu bildirilmiştir. Sicaklığ $60^{\circ} \mathrm{C}$ olan suya eriklerin 60 saniye daldırılması sonucu bozulmaların \%80'nin üzerinde azaldığı ve nektarinler de ise aynı sicaklık ve süre uygulamasının çürüme oranını $\% 5$ seviyesinin altına indirdiği görülmüştür. Dolayısıyla sıcak suya kısa süreli daldırma yaklaşımının sert çekirdekli meyvelerde Monilinia fructicola patojeni kontrolünde etkili olabileceği vurgulanmıştır.

Mikrobiyel antagonistlerin etkinliğini arttırmak amacıyla farklı çalışmalar yürütülmüştür. Hasat sonras1 ürünlerin korunmasinda kitozan gibi moleküller aracilığyla biyoaktif kaplama tekniğinin kullanılması günümüzde biyokoruyucu kültürler ile diğer moleküllerin ilişkisini 
tanımlamaktadır. Kitozan meyve ve sebzeleri fungal çürümelerden korumakta, çevre ile ürün arasında bariyer oluşturmakta ve ürünün olgunlaşmasını geciktirmektedir. Zhou vd. (2016) Pichia membranifaciens ve kitozan içeren bir karışım ile kaplanmış turunçgil meyvelerinin Colletotrichum gloeosporioides fungal enfeksiyonunu engelleme yeteneği üzerine çalışışlardır ve kaplama materyalinin maya kültürünün tek başına kullanıldığında gösterdiği etkiden daha etkili olduğunu belirlemişlerdir. Benzer şekilde 2hidroksibenzoik asit kullanımının Rhodotorula glutunis mayasının kiraz meyvelerinde $P$. expansum ve $A$. alternata küflerine karş1 biyokontrol etkinliğini arttırdığı bildirilmiştir (Qin vd., 2003).

\section{TİCARİ UYGULAMALAR}

Koruyucu içermeyen gidalara artan toplumsal ilgi bilim insanlarını antifungal kültürlerin biyokoruyucu olarak kullanılması yönünde güçlü bir şekilde teşvik etmiştir. Hasat sonrası hastalıkların kontrolü amacıyla son 30 yılda çok sayıda çalışma yapılarak büyük bir çaba harcanmasina rağmen çok az sayıda biyokontrol ürünü markette bulunmaktadır (Usall vd., 2016). Aday antifungal kültürlerin ticarileşmesini engelleyen çeşitli engeller bulunmaktadır. Bunlardan en önemlisi; mikroorganizmanın kültür ortamında (in vitro etki) gösterdiği aktivite ile gıda matriksinde gösterdiği (in situ etki) aktivite arasında önemli fark olmasıdır. Çok sayıda mikroorganizma ile in vitro koşullarda başarılı sonuçlar elde edilirken bu mikroorganizmaların sayıs hedef gidada test edilmeleri ile birlikte önemli bir şsekilde düşüş göstermektedir (Salas vd., 2017). Antagonistlerin kimyasal kontrol prosedürlerine kiyasla biyokontrol aktivitelerinin etkisizliği ve ekonomik teşvik yetersizliği antagonist maya adaylarının ticarileşmesinde karşılaşılan diğer zorluklardan bazılanıdır (Droby vd., 2009). Bu zorlukların dişında kullanılacak mikroorganizmaların belirli bir gida matriksine doğrudan eklenmesi mikroorganizmanın metabolizmasına bağlı olarak gidanın organoleptik kalitesi üzerinde pozitif, nötral veya negatif etki oluşturabilir. Örneğin, $\mathrm{CO}_{2}$ üreten suşlar ürün açısından (kabarcık veya hava boşluklarının oluşmasi) veya paketleme açısından (şişmiş paket) çeşitli etkilere yol açarken, diğer mikrobiyel adaylar kuvvetli enzimatik aktivite (proteolitik, amilolitik veya lipolitik) sergileyerek ürün tekstür ve genel özelliklerini doğrudan etkileyebilir (Salas vd., 2017). Bu bağlamda, antifungal kültür seçiminde kullanılacak kültürün ürünün alışılagelmiş tadını değiştirmemesi amaçlanmalı ve kültürün son ürünün organoleptik kalitesi üzerine muhtemel etkisi duyusal değerlendirme yapılarak belirlenmelidir. Yukarıda belirtilen engellerin ötesinde seçilen kültürlerin güvenli olması diğer belirleyici özelliklerden birisidir. Suş seçiminde güvenlik değerlendirmesi ve yasal düzenlemelerin yerine getirilmesi suşun biyoteknolojik kullanımı için kilit aşamalardan biri haline gelmiştir. $\mathrm{Bu}$ amaçla, Avrupa Birliği biyolojik ajanların geniş bir yelpazede güvenilirliğinin değerlendirilebilmesi amacıyla Nitelikli Güvenilirlik Varsayımı (Qualified Presumption of Safety - QPS) yaklaşımını geliştirmiştir (EFSA, 2016). Bu yaklaşım ile biyolojik ajanların gida ve yem katkıları, enzimler, bitki koruma ürünleri amacıyla kaynak olarak kullanılmas1 ve mikroorganizmaların besin üretiminde kullanımının market öncesi değerlendirilmesi yapılarak biyolojik ajanların güvenli bir şekilde kullanımı amaçlanmıştır. Benzer şekilde Amerika Birleşik Devletlerinde gida ve gidalarda kullanılan maddeler için genellikle güvenilir olarak kabul edilen (Generally Recognized as Safe - GRAS) statü bulunmaktadır (FDA, 2018).

Laboratuvar, yarı ticari ve ticari çalışmalarla hasat sonrası patojenlere karşı çok sayıda mikrobiyel antagonist (maya, bakteri) tanımlanmıştır. Ancak yukarıda belirtilen engellerden dolay1 bu antagonistlerin küçük bir kısmı üst düzey gelişim seviyelerine ulaşmış ve ticarileşmiştir. Candida oleophila (Aspire, Ecogen, ABD), Candida sake (Candifruit, IRTA, İspanya), Cryptococcus albidus (YieldPlus, Lallemand, Kanada), Pseudomonas syringae (BioSave, JET Harvest, ABD) onaylanıp satışa sunulan birinci nesil biyokontrol ürünleridir (Droby vd., 2016; Usall vd., 2016). Ancak bu ürünlerden Aspire ve Yieldplus yalnızca birkaç yıl satışa sunulabilmiş daha sonra ticari şartlar altında düşük ve tutarsız verimlilik, düşük kâr payı ve pazara girmede yaşanan zorluklar, müşterilerin ve endüstrinin bakış açısı, ürünleri geliştirmek ve 
ticarileştirmeyi sürdürmek için az kaynağa sahip küçük ölçekli şirketlerin bulunması gibi nedenlerden dolayı bu ürünler marketten geri çekilmiştir. Diğer taraftan bazı başarılı ticari uygulama örnekleri de bulunmaktadır (Çizelge 2). Örneğin; Shemer ticari adı ile bilinen Metschnikowia fructicola başlangıçta İsrail'de kayıt altına alınmış ve kayısı, turunçgiller, üzüm, şeftali, biber, çilek gibi birçok meyve-sebzede hasat öncesi ve sonrası uygulamalarda başarılı şekilde kullanılmıştır. Shemer ${ }^{\mathrm{TM}}$ daha sonra Bayer (Almanya) şirketi tarafından satın alınmış şu anda ise Koppert (Hollanda) şirketi alt lisansı olarak piyasada bulunmaya devam etmektedir (Spadaro ve Droby, 2016). Almanya'da geliştirilen ve BoniProtect ${ }^{\mathrm{TM}}$ ad1 altında bilinen Aureobasidium pullulans mayası yumuşak çekirdekli meyve ve sebzelerde depolama sirasinda Penicillium expansum, Botrytis cinerea ve Monilinia fructigena gibi çeşitli patojenler üzerine etkili olan başarılı ve geniş spektrumlu bir biyokontrol ürünüdür (Salas vd., 2017). Yakın zamanda Candida oleophila suşu içeren Nexy ticari ismi ile bilinen biyokontrol ürünü tüm Avrupa Birliği ülkeleri tarafindan kayıt onayını almıştır (Massart ve Jijakli, 2014).

Çizelge 2. Meyve-sebzelerde hasat sonrası hastalıkları kontrol etmek amacıyla geliştirilen ve ticari olarak temin edilebilen biyokoruyucu ürünler (Spadaro ve Droby, 2016; Salas vd., 2017)

\begin{tabular}{|c|c|c|c|c|}
\hline Ürün Ad 1 & Mikroorganizma & Hedef Patojenler & Uygulandığı Ürün & Üretici Ülke \\
\hline Aspire & Candida oleophila & $\begin{array}{l}\text { Penicillium expansum } \\
\text { Botrytis cinerea } \\
\text { Rhizopus stolonifer }\end{array}$ & $\begin{array}{l}\text { Turunçgiller } \\
\text { Yumuşak çekirdekli } \\
\text { meyveler } \\
\text { Elma } \\
\text { Șeftali }\end{array}$ & $\mathrm{ABD}$ \\
\hline Candifruit & Candida sake & $\begin{array}{l}\text { Penicillium expansum } \\
\text { Botrytis cinerea } \\
\text { Rhizopus stolonifer }\end{array}$ & $\begin{array}{l}\text { Yumuşak çekirdekli } \\
\text { meyveler }\end{array}$ & İspanya \\
\hline YieldPlus & $\begin{array}{l}\text { Cryptococcus } \\
\text { albidus }\end{array}$ & $\begin{array}{l}\text { Botrytis spp. } \\
\text { Penicillium spp. } \\
\text { Mucor spp. }\end{array}$ & $\begin{array}{l}\text { Yumuşak çekirdekli } \\
\text { meyveler Turunçgiller } \\
\text { Elma } \\
\text { Armut }\end{array}$ & Kanada \\
\hline BioSave & $\begin{array}{l}\text { Pseudomonas } \\
\text { syringae }\end{array}$ & $\begin{array}{l}\text { Penicillium expansum } \\
\text { Botrytis cinerea } \\
\text { Mucor piriformis } \\
\text { Fusarium sambucinum } \\
\text { Geotrichum candidum }\end{array}$ & $\begin{array}{l}\text { Yumuşak çekirdekli } \\
\text { meyveler } \\
\text { Turunçgiller } \\
\text { Patates } \\
\text { Kiraz } \\
\text { Elma } \\
\text { Armut }\end{array}$ & $\mathrm{ABD}$ \\
\hline BoniProtect & $\begin{array}{l}\text { Aureobasidium } \\
\text { pullulans }\end{array}$ & $\begin{array}{l}\text { Botrytis cinerea } \\
\text { Penicillium expansum } \\
\text { Monilinia fructigena }\end{array}$ & $\begin{array}{l}\text { Yumuşak çekirdekli } \\
\text { meyveler }\end{array}$ & Almanya \\
\hline Shemer & $\begin{array}{l}\text { Metschnikoowia } \\
\text { fructicola }\end{array}$ & $\begin{array}{l}\text { Aspergillus niger } \\
\text { Botrytis cinerea } \\
\text { Penicillium digitatum } \\
\text { Penicillium italicum } \\
\text { Rhizopus stolonifer } \\
\end{array}$ & $\begin{array}{l}\text { Üzüm, Çilek } \\
\text { Yer elması, Turunçgiller } \\
\text { Kayısı, Şeftali } \\
\text { Biber } \\
\text { Havuç } \\
\end{array}$ & Hollanda \\
\hline Nexy & Candida oleophila & $\begin{array}{l}\text { Botrytis cinerea } \\
\text { Penicillium expansum }\end{array}$ & $\begin{array}{l}\text { Yumuşak çekirdeli meyveler } \\
\text { Turunçgiller, Muz }\end{array}$ & Fransa \\
\hline
\end{tabular}


Çizelge 2. Devam

\begin{tabular}{lllll}
\hline Ürün Ad1 & Mikroorganizma & Hedef Patojenler & Uygulandığ1 Ürün & Üretici Ülke \\
\hline Pantovital & Pantoea & Botrytis cinerea & Turunçgil & İspanya \\
& aglomerans & Penicillium digitatum & Yumuşak çekirdekli & \\
& & Penicillium expansum & meyveler & \\
& & Rhizopus stolonifer & & \\
& & Monilinia spp. & & ABD \\
\hline Serenade & Bacillus subtilus & Monilinia fructicola & Üzüm, Elma & \\
& & Erninia amylovora & Armut & Güney \\
& & Phytophthora infestans & Yerfistığ1 & Afrika \\
\hline Avogreen & Bacillus subtilus & Cercospora spp. & Avokado & \\
& & Colletotrichum spp. & & \\
\hline
\end{tabular}

Ticarileșen antagonistik mikroorganizmaların ürüne uygulanma şeklide ürün verimliliği açısından önem arz etmektedir. Günümüzde antagonistik mikroorganizmaları meyve ve sebzelere uygularken genellikle püskürtme, daldırma, 1slatma veya kaplama yöntemleri kullanılmaktadır. Nebülizasyon yöntemi ticari antagonist ürünlerin uygulanmasında ortaya çıkan yeni yaklaşım yöntemlerindendir. Ticari antagonistlerin uygulanacağ1 ürünlerin sahip olduklar1 $\mathrm{pH}$, oksidatif stres, sicaklik ve su aktivitesi gibi özelliklerini belirleyen çevresel faktörler antagonist mikroorganizmaların canlılığ1 ve verimliliği üzerine etkili olmaktadır. Dolayısıyla antagonist ürünleri ticarileştiren şirketler ürün formülasyonu düzenlerken uygulanma yöntemini de dikkate almalı ve ürün kullanıcılarını uygulama metodu hakkında bilgilendirmelidir (Liu vd., 2013; Droby vd., 2016).

\section{SONUÇ}

Meyve ve sebzelerde hasat sonrası meydana gelen kayıplar gelişmekte olan veya gelişmiş olan ülkelerde dahi önemli oranlardadır. Son yıllarda yapılan bilimsel araştırmalar ile kayıp miktarlarının azaltılması konusunda çaba harcanmaktadır. Hasat sonrası hastalikların kimyasal kontrolü halen dünya genelinde en yaygin kullanilan yöntemdir. Günümüzde kimyasal kontrol yöntemine alternatif olarak antagonist mayaların kullanımı umut verici bir strateji olarak ön plana çıkmıştır. Mikrobiyel ajanların aktivite mekanizmaları tam olarak anlaşılamamış olsa da besin ve alan rekabeti ana mekanizma olarak düşünülmektedir. Ancak, günümüzde gelişen genomik, proteomik, metagenomik, transkriptomik ve metabolomik gibi yenilikçi ve güçlü moleküler teknikler araciliğıyla ürün, patojen ve antagonist arasındaki karmaşı 1 etkileşimlerin açılklğa kavuşturulacağ düşünülmektedir.

Antagonist olarak kullanılan çok sayıda mikroorganizma olmasına rağmen farklı meyve ve sebzelerde çeşitli patojenleri biyokontrolde başarılı oldukları belirlenen ve bu nedenle ilk olarak ticarileştirilen maya türlerinden başta Candida oleophila olmak üzere Aureobasidium pullulans, Metschnikowia pulcherrima ve Pichia guillermondii türleri ön plana çıkmaktadır. Candida oleophila türü hızlı kolonizasyon, oksidatif strese karş1 yüksek tolerans ve ürünün savuma mekanizmasını indüklemesi ile etki gösterirken Aureobasidium pullulans patojen hiflerine yapsşarak litik enzim üretme mekanizması ile patojenleri biyokontrolde etkili bulunmaktadır. Metschnikowia pulcherrima türü mikroorganizmalar için önemli bir bileşen olan ve hücre içi birçok proseste önemli rol oynayan demir emilimi mekanizması ile ön plana ç1karken, Pichia guillermondii patojen hiflerine yapışma, besin rekabeti ve ürünlerde bulunan patojenlere karşı savunmacı enzimlerin aktivitesini arttırma yoluyla etki göstermektedir.

Antagonist olarak kullanılan mayaların halen hasat sonras1 hastalıklar1 kontrolde pestisitler kadar etkili olmaması önemli bir sorun olarak ortaya çıkmaktadır. Ticari açıdan uygun uygulama metotlarının belirlenmesi için mikrobiyel ajanların etki mekanizmalarının detaylı bir şekilde 
anlaşılması zorunludur. Belirli ürün ve patojene özgü, kimyasal yöntemler ile rekabet edebilecek ve uygulama metodu optimize edilerek buna göre formülasyonu düzenlenmiş olan başarılı antagonist ürünlerin bulunması yöntemin geliştirilmesi gereken noktalarıdır.

\section{KAYNAKLAR}

Aloui, H., Licciardello, F., Khwaldia, K., Hamdi, M., Restuccia, C. (2015). Physical properties and antifungal activity of bioactive films containing Wickerbamomyces anamolus killer yeast and their application for preservation of oranges and control of postharvest green mold caused by Penicillium digitatum. Int J Food Microbiol, 200: 22-30. doi: 10.1016/j.ijfoodmicro.2015.01.015.

Anonim, (2017). Türkiye Cumhuriyeti Ekonomi Bakanlı̆̆ı. Yaş Meyve ve Sebze Sektörü: Sektör Raporlar1. İhracat Genel Müdürlüğü Tarım Ürünleri Daire Başkanlığı.

Arras, G., de-Cicco, V., Arru, S., Lima, G., (1998). Biocontrol by yeasts of blue mold of citrus fruits and the mode of action of an isolate of Pichia guilliermondii. J Hortic Sci, 73(3): 413-418. doi: 10.1080/14620316.1998.11510993.

Bautista-Rosales, P. U., Calderon-Santoyo, M., Servín-Villegas, R., Ochoa-Álvarez, N. A., Ragazzo-Sánchez, J. A. (2013). Action mechanisms of the yeast Candida fermentati for the control of thephytopathogen Colletotrichum gloeosporioides in mangoes. Biol Control, 65(3): 293301. doi: 10.1016/j.biocontrol.2013.03.010.

Calvo, H., Marco, P., Blanco, D., Oria, R., Venturini, M.E. (2017). Potential of a new strain of Bacillus amyloliquefaciens BUZ-14 as a biocontrol agent of postharvest fruit diseases. Food Microbiol, 63: 101-110. doi: 10.1016/j.fm.2016.11.004.

Campos-Martínez, A., Velázquez-del Valle, M.G., Flores-Moctezuma, H.E., Suárez-Rodríguez, R., Ramírez-Trujillo, J.A., Hernández-Lauzardo, A.N. (2016). Antagonistic yeasts with potential to control Colletotrichum gloeosporioides (Penz.) Penz. \& Sacc. and Colletotrichum acutatum J.H. Simmonds on avocado fruits. Crop Prot, 89: 101-104. doi: 10.1094/PDIS-10-14-1019-PDN.
Cao, J., Zhang, H., Yang, Q., Ren, R. (2013). Efficacy of Picbia caribbica in controlling blue mold rot and patulin degradation in apples. Int J Food Microbiol, 162(2): 167 173. doi: 10.1016/j.ijfoodmicro.2013.01.007.

Castoria, R., Caputo, L., De Curtis, F., De Cicco, V. (2003). Resistance of postharvest biocontrol yeasts to oxidative stress: a possible new mechanism of action. Phytopathology, 93(5): 564 572. doi: 10.1094/PHYTO.2003.93.5.564.

de Paiva, E., Serradilla, M. J., Ruiz-Moyano, S., Cordoba, M. G., Villalobos, M. C., Casquete, R., Hernandez, A. (2017). Combined effect of antagonistic yeast and modified atmosphere to control Penicillium expansum infection in sweet cherries cv. Ambrunes. Int J Food Microbiol, 241: 276-282. doi: 10.1016/j.ijfoodmicro.2016.10.033.

Di Francesco, A., Ugolini, L., Lazzeri, L., Mari, M. (2015). Production of volatile organic compounds by Aureobasidium pullulans as a potential mechanism of action against postharvest fruit pathogens. Biol Conrol, 81: 8-14. doi: 10.1016/j.biocontrol.2014.10.004.

Droby, S., Wisniewski, M., Macarisin, D., Wilson, C. (2009). Twenty years of postharvest biocontrol research: Is it time for a new paradigm? Postharvest Biol Tec, 52(2): 137-145. doi: 10.1016/ j.postharvbio.2008.11.009.

Droby, S., Wisniewski, M., Teixidó, N., Spadaro, D., Jijakli, M. H. (2016). The science, development, and commercialization of postharvest biocontrol products. Postharvest Biol Tec, 122: 22-29. doi: 10.1016/j.postharvbio. 2016.04.006.

EFSA, 2014. The 2011 European Union report on pesticide residues in food. Efsa J. 12(5), 3694, Parma, Italy.

EFSA (2016). Panel on Biological Hazards (BIOHAZ). Update of the list of QPSrecommended biological agents intentionally added to food or feed as notified to EFSA 4: Suitability of taxonomic units notified to EFSA until March 2016. Efsa J, 14(7): 4522. doi: 10.2903/j.efsa.2016.4522. 
FAO. (2011). Global food losses and food waste: extent, causes and prevention. http://www.fao.org/docrep/014/mb060e/mb0 60e.pdf (Erişildi 21 Mayıs 2018).

FDA. (2018). Generally Recagnized as Safe (GRAS).https://www.fda.gov/Food/

Ingredients PackagingLabeling/GRAS/ (Erişildi 21 Mayıs 2018).

Ferraz, L.P., da Cunha, T., da Silva, A.C., Kupper, K.C. (2016). Biocontrol ability and putative mode of action of yeasts against Geotrichum citri aurantii in citrus fruit. Microbiol Res, 188-189: 72-79. doi:10.1016/j.micres.2016.04.012.

Gajbhiye, M.H., Sathe, S.J., Marathe, R.J., Deshmukh, R.B. (2013). Antifungal Bacillus subtilis AFB22 from pomegranate with potential to control fruit rot. Res J Biotechnol, 8(3): 26-35.

Gong, C., Liu, Y., Liu, S., Cheng, M., Zhang, Y., Wang, R., Chen, H., Li, J., Chen, X., Wang, A. (2017). Analysis of Clonostachys rosea-induced resistance to grey mould disease and identification of the key proteins induced in tomato fruit. Postharvest Biol Tec, 123: 83-93. doi: 10.1016/j.postharvbio.2016.08.004.

Gotor-Vila, A., Teixidó, N., Di Francesco, A., Usall, J., Ugolini, L., Torres, R., Mari, M. (2017). Antifungal effect of volatile organic compounds produced by Bacillus amyloliquefaciens CPA-8 against fruit pathogen decays of cherry. Food Microbiol, 64: 219-225. doi:10.1016/j.fm. 2017.01.006.

González-Estrada, R. R., Carvajal-Millán, E., Ragazzo-Sánchez, J. A., Bautista-Rosales, P. U., Calderón-Santoyo, M. (2017). Control of blue mold decay on Persian lime: Application of covalently cross-linked arabinoxylans bioactive coatings with antagonistic yeast entrapped. J Food Sci Technol, 85(A): 187-196. doi: 10.1016/j.lwt. 2017.07.019.

Hossain, M. I., Sadekuzzaman, M., Ha, S. D. (2017). Probiotics as potential alternative biocontrol agents in the agriculture and food industries. Food Res Int, 100(1): 63-73. doi: 10.1016/j.foodres.2017.07.077.
Ippolito, A., Nigro, F. (2000). Impact of preharvest application of biological control agents on postharvest diseases of fresh fruit and vegetables. Crop Prot, 19 (8/10): 715-723. doi: 10.1016/S0261-2194(00)00095-8.

Kang, Y., Bai, D., Tapia, L., Bateman, H. (2017). Dynamical effects of biocontrol on the ecosystem: Benefits or harm? ApplMath Model, 51: 361-385 doi: 10.1016/j.apm.2017.07.006.

Karabulut, O. A., Smilanick, J. L., Crisosto, C. H., and Palou, L. (2010). Control of brown rot of stone fruits by brief heated water immersion treatments. Crop Prot, 29(8): 903-906.

Kalogiannis, S., Tjamos, S.E., Stergiou, A., Antoniou, P.P., Ziogas, B.N., Tjamos, E.C. (2006). Selection and evaluation of phyllosphere yeasts as biocontrol agents against grey mould of tomato. Eur J Plant Pathol, 116(1): 69-76. doi: 10.1007/s10658-006-9040-5.

Kim, Y.S., Balaraju, K., Jeon, Y. (2016). Effects of rhizobacteria Paenibacillus polymyxa APEC136 and Bacillus subtilis APEC170 on biocontrol of postharvest pathogens of apple fruits. J Zhejiang Univ Sci B, 17(12): 931-940. doi:10.1631/jzus.B1600117.

Kilani-Feki, O., Khedher, S.B., Dammak, M., Kamoun, A., Jabnoun-Khiareddine, H., DaamiRemadi, M., Tounsi, S. (2016). Improvement of antifungal metabolites production by Bacillus subtilis V26 for biocontrol of tomato postharvest disease. Biol Control, 95: 73-82. doi:10.1016/j.biocontrol.2016.01.005.

Kwasiborski, A., Bajji, M., Renaut, J., Delaplace, P., Jijakli, H. (2014). Identification of metabolic pathways expressed by Pichia anomala Kh6 in the presence of the pathogen Botrytis cinerea on apple: new possible targets for biocontrol improvement. PLoS ONE, 9(3): e91434. doi: 0.1371/ journal.pone. 091434.

Lamont, J.R., Wilkins, O., Bywater-Ekegärd, M., Smith, D. L. (2017). From yogurt to yields: potential applications of lactic acid bacteria in plant production. Soil Biol Biochem, 111: 1-9. doi: 10.1016/j.soilbio.2017.03.015. 
Junior W. J. F. L, Treu L., Duarte V. S., Campanaro S., Nadai C., Giacomini A., Coricha V. (2017). Draft Genome Sequence of the Yeast Starmerella bacillaris (syn., Candida zemplinina) FRI751 Isolated from Fermenting Must of Dried Raboso Grapes. Genome Announc, 5(17): e0022417. doi:10.1128/genomeA.00224-17.

Li, W., Zhang, H., Li, P., Apaliya, M.T., Yang, Q., Peng, Y., Zhang, X. (2016). Biocontrol of postharvest green mold of oranges by Hanseniaspora uvarum Y3 in combination with phosphatidylcholine. Biol Control, 103: 30-38. doi: 10.1016/j.biocontrol.2016.07.014.

Lipinska, L., Klewicki, R., Klewicka, E., Kolodziejczyk, K., Sojka, M., Nowak, A. (2016). Antifungal Activity of Lactobacillus sp Bacteria in the Presence of Xylitol and Galactosyl Xylitol. Biomed Res Int, 2016: 8. doi: 10.1155/2016/ 5897486.

Li, B.Q., Tian, S.P. (2006). Effects of trehalose on stress tolerance and biocontrol efficacy of Cryptococcus laurentii. J Appl Microbiol, 100(4): 854861. doi: 10.1111/j.1365-2672.2006.02852.x.

Liu, J., Wisniewski, M., Droby, S., Tian, S., Hershkovitz, V., Tworkoski, T. (2011). Effect of heat shock treatment on stress tolerance and biocontrol efficacy of Metschnikowia fructicola. FEMS Microbiol Ecol, 76(1): 145-155. doi: 10.1111/j.1574-6941.2010.01037.x

Liu, J., Wisniewski, M., Droby, S., Norelli, J., Hershkovitz, V., Tian, S., Farrell, R. (2012). Increase in antioxidant gene transcripts, stress tolerance and biocontrol efficacy of Candida oleophila following sublethal oxidative stress exposure. FEMS Microbiol Ecol, 80(3): 578-590. doi: 10.1111/j.1574-6941.2012.01324.x.

Liu, J., Wisniewski, M., Artlip, T., Sui, Y., Droby, S., Norelli, J. (2013). The potential role of PR-8 gene of apple fruit in the mode of action of the yeast antagonist, Candida oleophila, in postharvest biocontrol of Botrytis cinerea. Postharvest Biol Tec, 85: 203-209.

doi: 10.1016/j.postharvbio.2013.06.007.

Liu, P., Cheng, Y., Yang, M., Liu, Y., Chen, K., Long, C. Deng X. (2014). Mechanisms of action for 2-phenylethanol isolated from Kloeckera apiculata in control of Penicillium molds of citrus fruits. BMC Microbiol, 14: 242 . doi: 10.1186/s12866-014-0242-2.

Liu, Y., Wang, W., Zhou, Y., Yao, S., Deng, L., Zeng, K. (2017). Isolation, identification and in vitro screening of Chongqing orangery yeasts for the biocontrol of Penicillium digitatum on citrus fruit. Biol Control, 110: 18-24. doi: 10.1016/j.biocontrol. 2017.04.002.

Macarisin, D., Droby, S., Bauchan, G., Wisniewski, M. (2010). Superoxide anion and hydrogen peroxide in the yeast antagonist-fruit interaction: a new role for reactive oxygen species in postharvest biocontrol? Postharvest Biol Tec, 58(3): 194-202. doi: 10.1016/j.postharvbio. 2010.07.008.

Mahunu, G. K., Zhang, H., Yang, Q., Zhang, X., Li, D., Zhou, Y. (2016). Improving the biocontrol efficacy of Pichia caribbica with phytic acid against postharvest blue mold and natural decay in apples. Biol Control, 92: 172-180. doi: 10.1016/j.biocontrol.2015.10.012.

Massart, S., Jijakli, M.H., (2014). Pichia anomala and Candida oleophila in biocontrol of postharvest diseases of fruits: 20 years of fundamental and practical research. In: Post-Harvest Pathology. Plant Pathology in the 21st Century: Contributions to the 10th International Congress of Plant Pathology, Prusky, D., Gullino, M.L. (chief eds.), , Volume 7. Springer, The Netherlands, pp. 111-122. doi: 10.1007/9783-319-07701-7_10.

Nagaraja, H., Chennappa, G., Rakesh, S., Naik, M.K., Amaresh, Y.S., Sreenivasa, M.Y. (2016). Antifungal activity of Azotobacter nigricans against trichothecene-producing Fusarium species associated with cereals. Food Sci Biotechnol, 25(4): 1197-1204. doi: 10.1007/s10068-016-0190-8.

Nally, M. C., Pesce, V. M., Maturano, Y. P., Rodriguez Assaf, L. A., Toro, M. E., Castellanos de Figueroa, L. I., Vazquez, F. (2015). Antifungal modes of action of Saccharomyces and other biocontrol yeasts against fungi isolated from sour and grey rots. Int J Food Microbiol, 204: 91-100.

Nunes, C.A. (2012) . Biological control of postharvest diseases of fruit. Eur J Plant Pathol 
133(1): 181-196. doi: 10.1007/s10658-011-99197.

Oregel-Zamudio, E., Angoa-Pérez, M. V., Oyoque-Salcedo, G., Aguilar-González, C. N., Mena-Violante, H. G. (2017). Effect of candelilla wax edible coatings combined with biocontrol bacteria on strawberry quality during the shelflife. Sci Hortic, 214: 273-279. doi: 10.1016/j.scienta.2016.11.038.

Pantelides, I.S., Christou, O., Tsolakidou, M.-D., Tsaltas, D., Ioannou, N. (2015). Isolation, identification and in vitro screening of grapevine yeasts for the control of black aspergilli on grapes. Biol Control, 88: 46-53. doi: 10.1016/j.biocontrol. 2015.04.021.

Parafati, L., Vitale, A., Restuccia, C., Cirvilleri, G. (2015). Biocontrol ability and action mechanism of food-isolated yeast strains against Botrytis cinerea causing post-harvest bunch rot of table grape. Food Microbiol, 47: 85-92. doi: 10.1016/j.fm. 2014.11.013

Parafati L., Vitale A., Restuccia C., Cirvilleri G. (2017). "Performance evaluation of volatile organic compounds by antagonistic yeasts immobilized on hydrogel spheres against gray, green and blue postharvest decays." Food Microbiol, 63: 191-198. doi: 10.1016/j.fm.2016.11.021.

Passera, A., Venturini, G., Battelli, G., Casati, P., Penaca, F., Quaglino, F., Bianco, P.A. (2017). Competition assays revealed Paenibacillus pasadenensis strain R16 as a novel antifungal agent. Microbiol Res, 198: 16-26. doi:10.1016/j.micres. 2017.02.001.

Prendesa P. L., Merín G. M., Fontana R. A., Bottini A. R., Ramirez L. M., Morata de Ambrosini I. V. (2018). "Isolation, identification and selection of antagonistic yeast against Alternaria alternata infection and tenuazonic acid production in wine grapes from Argentina." Int J Food Microbiol, 266: 14-20. doi: 10.1016/ j.ijfoodmicro.2017.10.033

Pesce, V. M., Nally, M. C., Carrizo, G. P., Rojo, C., Pérez, B. A., Toro, M. E., Castellanos de Figueroa, L. I., Vazquez, F. (2018). Antifungal activity of native yeasts from different microenvironments against Colletotrichum gloeosporioides on ripe olive fruits. Biol Control, 120: 43-51. doi: 10.1016/j.biocontrol.2017.03.005.

Perez, M. F., Perez Ibarreche, J., Isas, A. S., Sepulveda, M., Ramallo, J., Dib, J. R. (2017). Antagonistic yeasts for the biological control of Penicillium digitatum on lemons stored under export conditions. Biol Control, 115: 135-140. doi: 10.1016/j.biocontrol.2017.10.006.

Perez, M.F., Contreras, L., Garnica, N.M., Fernández-Zenoff, M.V., Farías, M.E., Sepulveda, M., Ramallo, J., Dib, J.R. (2016). Native killer yeasts as biocontrol agents of postharvest fungal diseases in lemons. PLoS ONE, 11(10): e-0165590.doi: 10.1371/ journal.pone.0165590.

Romanazzi, G., Feliziani, E., Baños, S. B., Sivakumar, D. (2017). Shelf life extension of fresh fruit and vegetables by chitosan treatment. Crit Rev Food Sci Nutr, 57(3): 579-601. doi: 10.1080/10408398.2014.900474.

Ruiz-Moyano, S., Martín, A., Villalobos, M. C., Calle, A., Serradilla, M. J., Córdoba, M. G., Hernández, A. (2016). Yeasts isolated from figs (Ficus carica L.) as biocontrol agents of postharvest fruit diseases. Food Microbiol, 57: 45-53. doi: 10.1016/j.fm.2016.01.003

Spadaro, D., Lorè, A., Garibaldi, A., Gullino, L. M. (2013). A new strain of Metschnikowia fructicola for postharvest control of Penicillium expansum and patulin accumulation on four cultivars of apple. Postharvest Biol Tec, 75: 1-8. doi: 10.1016/j.postharvbio.2012.08.001.

Salas, M. L., Mounier, J., Valence, F., Coton, M., Thierry, A., Coton, E. (2017). Antifungal Microbial Agents for Food Biopreservation. Microorganisms, 5(3). doi: 10.3390/ microorganisms 5030037 .

Qin, X., Xiao, H., Xue, C., Yu, Z., Yang, R., Cai, Z., Si, L. (2015). Biocontrol of gray mold in grapes with the yeast Hanseniaspora uvarum alone and in combination with salicylic acid or sodium bicarbonate. Postharvest Biol Tec, 100: 160-167. doi: 10.1016/j.postharvbio.2014.09.010.

Qin, G.Z., Tian, S.P., Xu, Y., Wan, Y.K. (2003). Enhancement of biocontrol efficacy of 
antagonistic yeasts by salicylic acid in sweet cherry fruit. Physiol Mol Plant Pathol, 62(3): 147-154. doi: 10.1016/S0885-5765(03)00046-8

Saravanakumar, D., Clavorella, A., Spadaro, D., Garibaldi, A., Gullino, M. L. (2008). Metschnikowia pulcherrima strain MACH1 outcompetes Botrytis cinerea, Alternaria alternata and Penicillium expansum in apples through iron depletion. Postharvest Biol Tec, 49(1): 121-128. doi: 10.1016/j.postharvbio.2007.11.006.

Sharma, R. R., Singh, D., Singh, R. (2009). Biological control of postharvest diseases of fruits and vegetables by microbial antagonists. Biol Control, 50(3): 205-221. doi: 10.1016/j.biocontrol. 2009.05.001

Spadaro, D., Ciavorella, A., Zhang, D., Garibaldi, A., Gullino, M. L. (2010). Effect of culture media and $\mathrm{pH}$ on the biomass production and biocontrol efficacy of a Metschnikowia pulcherrima strain to be used as a biofungicide for postharvest disease control. Can J Microbiol, 56(2): 128-137. doi: 10.1139/w09-117.

Spadaro, D., Droby, S. (2016). Development of biocontrol products for postharvest diseases of fruit: The importance of elucidating the mechanisms of action of yeast antagonists. Trends Food Sci Technol, 47: 39-49. doi: 10.1016/j.tifs. 2015.11.003.

Sui, Y., Liu, J. (2014). Effect of glucose on thermotolerance and biocontrol efficaciy of the antagonistic yeast Pichia guilliermondii. Biol Control, 74: 59-64. doi: 10.1016/j.biocontrol.2014.04.003.

Sun, C., Fu, D., Lu, H., Zhang, J., Zheng, X., Yu, T. (2018). Autoclaved yeast enhances the resistance against Penicillium expansum in postharvest pear fruit and its possible mechanisms of action. Biol Control, 119: 51-58. doi: 0.1016/j.biocontrol.2018.01.010.

Tang, J., Liu, Y., Li, H., Wang, L., Huang, K., Chen, Z. (2015). Combining an antagonistic yeast with harpin treatment to control postharvest decay of kiwifruit. Biol Control, 89: 61-67. doi: 10.1016/j.biocontrol.2015.04.025.

Terao, D., Nechet, K., Ponte, S. M., Maia, N. A., Anjos, D. A. V., Halfed- Vieria A. B. (2017).
"Physical postharvest treatments combined with antagonistic yeast on the control of orange green mold." Sci Hortic, 224: 317-323. doi: 10.1016/ j.scienta.2017.06.038.

Teixidó, N., Viñas, I., Usall, J., Magan, N., (1998). Improving ecological fitness and environmental stress tolerance of the biocontrol yeast Candida sake by manipulation of intracellular sugar alcohol and sugar content. Mycol Res, 102(11): 1409-1417. doi: 10.1017/S0953756298006716.

Usall, J., Torres, R., Teixidó, N. (2016). Biological control of postharvest diseases on fruit: a suitable alternative? Curr Opin Food Sci, 11: 51-55. doi: 10.1016/j.cofs.2016.09.002.

Yang, Q., Wang, H., Zhang, H., Zhang, X., Apaliya, M.T., Zheng, X., Mahunu, G.K. (2017). Effect of Yarrowia lipolytica on postharvest decay of grapes caused by Talaromyces rugulosus and the protein expression profile of $T$. rugulosus. Postharvest Biol Tec, 126: 15-22. doi: 10.1016/j.postharvbio.2016.11.015.

Vero, S., Garmendia, G., González, M. B., Bentancu, O., Wisniewski, M. (2013). Evaluation of yeasts obtained from Antarctic soil samples as biocontrol agents for the management of postharvest diseases of apple (Malus $\times$ domestica). FEMS Yeast Res, 13(2), 189-199.

Wang, Y., Wang, P., Xia, J., Yu, T., Luo, B., Wang, J., Zheng, X. (2010). Effect of water activity on stress tolerance and biocontrol activity in antagonistic yeast Rhodosporidium paludigenum. Int J Food Microbiol, 143(3): 103-108. doi: 10.1016/ j.ijfoodmicro.2010.07.035.

Wei, Y., Mao, S., Tu, K. (2014). Effect of preharvest spraying Cryptococcus laurentii on postharvest decay and quality of strawberry. Biol Control, 73: 68-74. doi: 10.1016/j.biocontrol. 2014.02.016.

Xu, X., Zhang, H., Chen, K., Xu, Q., Yao, Y., Gao, H. (2013). Biocontrol of postharvest Rhizopus decay of peaches with Pichia caribbica. Curr Microbiol, 67(2): 255-261. doi: 10.1007/s00284-013-0359-9.

Zhao, Y., Tu, K., Shao, X., Jing, W., Su, Z., (2008). Effects of the yeast Pichia guilliermondii against 
Rhizopus nigricans on tomato fruit. Postharvest Biol Tec, 49 (1): 113-120. doi: 10.1016/j.postharvbio. 2008.01.001.

Zhang, C.H., Li, Y., Liu, P., Liu, M.J. (2015). Identification of two Bacillus amyloliquefaciens strains with high suppression to the key fruit pathogens of Chinese jujube. Biocontrol Sci Technol, 25(5): 573-582. doi: 10.1080/09583157. 2014.997675 .

Zhang, Z., Chen, J., Li, B., He, C., Chen, Y., Tian, S. (2017). Influence of Oxidative Stress on Biocontrol Activity of Cryptococcus laurentii against Blue Mold on Peach Fruit. Front Microbiol, 8: 151. doi:10.3389/fmicb.2017.00151
Zhou, Y., Zhang, L., Zeng, K. (2016). Efficacy of Pichia membranaefaciens combined with chitosan against Colletotrichum gloeosporioides in citrus fruits and possible modes of action. Biol Control, 96: 39-47. doi: 10.1016/j.biocontrol. 2016.02.001.

Zhimo, V.Y., Dilip, D., Sten, J., Ravat, V.K., Bhutia, D.D., Panja, B., Saha, J. (2017). Antagonistic Yeasts for Biocontrol of the Banana Postharvest Anthracnose Pathogen Colletotrichum musae. J Phytopathol, 165(1): 35-43. doi: 10.1111/jph.12533. 